\title{
Effect of abiotic factors on the molluscicidal activity of oleoresin of Zingiber officinale against the snail Lymnaea acuminata
}

\author{
Vijya Singh, Pradeep Kumar, Vinay Kumar Singh, Dinesh Kumar Singh* \\ Malacology Laboratory, Department of Zoology, D. D. U., Gorakhpur University, Gorakhpur, India; *Corresponding Author: \\ dksingh_gpu@yahoo.co.in.
}

Received 28 April 2010; revised 30 May 2010; accepted 3 June 2010.

\section{ABSTRACT}

Earlier it has been observed that oleoresin of Zingiber officinale is a potent molluscicide against Lymnaea acuminata. This snail is the vector of Fasciola species, which cause endemic fascioliasis in eastern Uttar Pradesh. As this snail breeds and maintain their population constant through out the year, so that the present study has been designed to find out the effect of variations in some environmental factors in different seasons, on the molluscicidal activity of oleoresin of Zingiber officinale and its relative effect on certain enzymes viz., acetylcholinesterase, acid and alkaline phosphatases in the nervous tissue of the snail Lymnaea acuminata. In this study temperature, $\mathrm{pH}$, dissolve oxygen, free carbon dioxide, conductivity of the water in control, as well as molluscicide treated water, was measured simultaneously. LC $_{50}$ value of oleoresin was determined in each month of the year. Toxicity of oleoresin in June-July $(24 \mathrm{~h}$ $\mathrm{LC}_{50}$ 16.54-14.28 $\mathrm{mgL}^{-1}$ ) is highest. Acetylcholinesterase, acid and alkaline phosphatases activity in the nervous tissue of the snails treated with sub-lethal concentration of oleoresin was simultaneously measured. Sig- nificant positive rank correlation, in between the acetylcholinesterase or acid phosphatase activity and $\mathbf{L C}_{50}$ of oleoresin was observed. The pre- sent study conclusively shows that variant abi- otic factors can significantly alter the toxicity of oleoresin of $Z$. officinale in $L$. acuminata. The most suitable period for control of $L$. acuminata is June-July.

Keywords: Environmental factors;

Acetylcholinesterase; Oleoresin; Temperature; $\mathrm{pH}$

\section{INTRODUCTION}

It has been reported that, oleoresin of Zingiber officinale is a potent molluscicide [1,2]. Fresh water snail Lymnaea acuminata is the intermediate host of liver fluke Fasciola gigantica, causing an endemic fascioliasis in the cattle population of eastern region of the state of Uttar Pradesh in India [3,4]. An effective method to reduce the incidence of fascioliasis is to control the population of vector snails and, thereby, break the life cycle of these flukes [5-8]. Earlier studies have shown that oleoresin of Zingiber officinale has a powerful molluscicidal action on the snail $L$. acuminate $[1,2]$. It has also been conclusively shown that acetylcholinesterase (AChE), acid and alkaline phosphatase (ACP and ALP) in the nervous tissue of L. acuminata are very sensitive parameters influenced by molluscicides [7-10]. The aim of the present study was to explore the possibility whether seasonal changes in abiotic factors, viz temperature, $\mathrm{pH}$, dissolved oxygen and carbon dioxide, and conductivity of test water can influence the level of AChE, ACP and ALP assayed in each month of the year 2006-2007 following exposure to sublethal concentrations $(40 \%$ and $80 \%)$ of $24 \mathrm{~h} \mathrm{LC}_{50}$ of oleoresin of $Z$. officinale.

\section{MATERIALS AND METHODS}

\subsection{Test Materials}

Oleoresin was obtained by extraction of prepared dried rhizomes of $Z$. officinale with alcohol. The removal of the solvent under vacuum yields oleoresin of $Z$. officinale [1,11]. Temperature, $\mathrm{pH}$ and conductivity of water were measured by thermometer and digital $\mathrm{pH}$ and conductivity meters, respectively. Dissolved $\mathrm{O}_{2}$ and $\mathrm{CO}_{2}$ were estimated according to the methods prescribe by APHA [12]. 


\subsection{Bioassays for $\mathbf{L C}_{50}$}

Adult L. acuminata (length $2.25 \pm 0.2 \mathrm{~cm}$ ) were collected from Ramgarh Lake, located in almost adjacent to this university campus. Snails were acclimatized in de-chlorinated tap water for $72 \mathrm{~h}$. The snails were exposed to different concentrations of oleoresin in glass aquaria containing 3 litres of de-chlorinated water. Ten experimental animals were kept in each aquarium. Control animals were kept in equal volumes of de-chlorinated tap water under similar conditions. Mortality of snails was observed after $24,48,72,96 \mathrm{~h}$. No response to a needle probe was taken as evidence of death. Dissolved $\mathrm{O}_{2}, \mathrm{CO}_{2}$ and conductivity, temperature and $\mathrm{pH}$ of treated and control group of water was measured simultaneously with toxicity test at every $24 \mathrm{~h}$ of period to 96 . Bioassays for the determination of $\mathrm{LC}_{50}$ value was performed in each month of the year. Lethal concentration $\left(\mathrm{LC}_{50}\right)$ values, lower and upper confidence limits (LCL and UCL) and slopes value were calculated by the method of POLO computer program of Robertson et al. [13]. The Product moment correlation coefficient was determined between $\mathrm{LC}_{50}$ and temperature / $\mathrm{pH} /$ conductivity / dissolved $\mathrm{O}_{2} / \mathrm{CO}_{2}$, of water in each of the twelve months in order to observe any significant correlation according to the method of Sokal and Rohlf [14].

\subsection{Enzyme Assays}

Twenty snails, kept in glass aquaria containing 5 litres of dechlorinated water, were exposed to $40 \%$ and $80 \%$ of $24 \mathrm{~h} \mathrm{LC}_{50}$ of oleoresin in each month. Six such aquaria were set up for each concentration. After $24 \mathrm{~h}$ treatment, the snails were washed with water and the nervous tissue was dissected out from the buccal mass for the measurement of enzyme AChE, ACP and ALP activities.

\subsubsection{Acetylcholinesterase}

Acetylcholinesterase (AChE) activity was measured according to the method of Ellman et al. [15] as modified by Singh et al. [16]. Fifty mg of nervous tissue was homogenized in $1.0 \mathrm{ml}$ of $0.1 \mathrm{M}$ phosphate buffer $\mathrm{pH}$ 8.0 for 5 minute in an ice bath and centrifuged at $1000 \mathrm{~g}$ for 30 minute at $4^{\circ} \mathrm{C}$. Supernatant was used as enzyme source. The change in optical density at $412 \mathrm{~nm}$ was recorded for 3 minute after every 30 second interval. Enzyme activity was expressed as $\mu$ mol "SH" hydrolyzed / $\mathrm{min} / \mathrm{mg}$ protein.

\subsubsection{Phosphatases}

Acid (ACP) and alkaline (ALP) phosphatases activities were measured by the method of Bergmeyer [17] as modified by Singh and Agarwal [18]. Tissue homogenate $(2 \% \mathrm{w} / \mathrm{v})$ was prepared in ice cold $0.9 \% \mathrm{NaCl}$ and centrifuged at $5000 \mathrm{~g}$ for 20 minute at $4^{\circ} \mathrm{C}$. The 4-nitro- phenyl phosphate disodium was used as substrate. The acid (ACP) and alkaline phosphatases (ALP) activity has been expressed as $\mu$ mole substrate hydrolyzed $/ 30 \mathrm{~min} /$ mg protein.

\subsubsection{Protein Estimation}

Protein was estimated by the method of Lowry et al. [19].

\subsection{Statistical Analysis}

Results have been expressed as mean \pm SE of six replicates. Rank correlation was applied in between control and corresponding changes in the enzyme activity in different months of the year [14].

\section{RESULTS}

There was a significant $(\mathrm{P}<0.05)$ time dependent variation in the toxicity of oleoresin $Z$. officinale in different months of the year against $L$. acuminata (Table 1); highest toxicity was observed in months of June and July (24 h LC 50 14.28-16.54 $\left.\mathrm{mgL}^{-1}\right)$ and lowest $\left(24 \mathrm{~h} \mathrm{LC}_{50}\right.$ 124.09-126.27 $\left.\mathrm{mgL}^{-1}\right)$ during January and February. A significant positive correlation $(r=0.89 ; P=0.001)$ between $\mathrm{LC}_{50}$ and water $\mathrm{pH}$ was noted for each month and at each interval of $24 \mathrm{~h}$ exposure (Table 1). A similar finding between $\mathrm{LC}_{50}$ and dissolved $\mathrm{O}_{2}(r=0.82 ; P=$ $0.001)$ was found. Contrastively, significant negative correlation between $\mathrm{LC}_{50}$ and dissolved $\mathrm{CO}_{2}(r=0.86 ; P$ $=0.001)$ and with water temperature $(r=0.91 ; P=0.001)$ was noted. No marked correlation was observed between the $\mathrm{LC}_{50}$ and conductivity of water. High temperature $\left(36^{\circ} \mathrm{C}\right)$, and free $\mathrm{CO}_{2}(30.0 \mathrm{ppm})$, low $\mathrm{pH}$ (7.11) and dissolved oxygen $(1.0 \mathrm{ppm})$ increases the toxicity of oleoresin against $L$. acuminata. The slope values were steep and separate estimations of $\mathrm{LC}_{50}$ based on each of the six replicates were found to be with in the $95 \%$ confidence limits of $\mathrm{LC}_{50}$. The t-ratio is greater than 1.96 and the heterogeneity factor is less than 1.0. The $g$ value was less than 0.5 at all probability levels.

There was significant positive rank correlation $(\tau=$ $0.666 ; P=0.02-40 \%$ of $24 \mathrm{~h} \mathrm{LC}_{50}, \tau=0.636, P=0.02-$ $80 \%$ of $24 \mathrm{~h} \mathrm{LC}_{50}$ ) between $\mathrm{LC}_{50}$ of different months and corresponding anti $\mathrm{AChE}$ activity in the sub-lethal treatment $\left(40 \%\right.$ and $80 \%$ of $\left.24 \mathrm{~h} \mathrm{LC}_{50}\right)$ of nervous tissue of snail L. acuminata. Maximum inhibition in AChE activity (56.09\% of control) was observed in snails exposed to $80 \%$ of $24 \mathrm{~h} \mathrm{LC}_{50}$ of oleoresin in month of July (Table 2). There was no significant positive rank correlation between $\mathrm{LC}_{50}$ of different months and alkaline phosphatase activity in the sub-lethal treatment $(40 \%$ and $80 \%$ of $24 \mathrm{~h} \mathrm{LC}_{50}$ ) of nervous tissue of snail $\mathrm{L} . \mathrm{acu}$ minata (Table 3). Like AChE, there was significant positive rank correlation between $\mathrm{LC}_{50}$ and acid phosphatas 


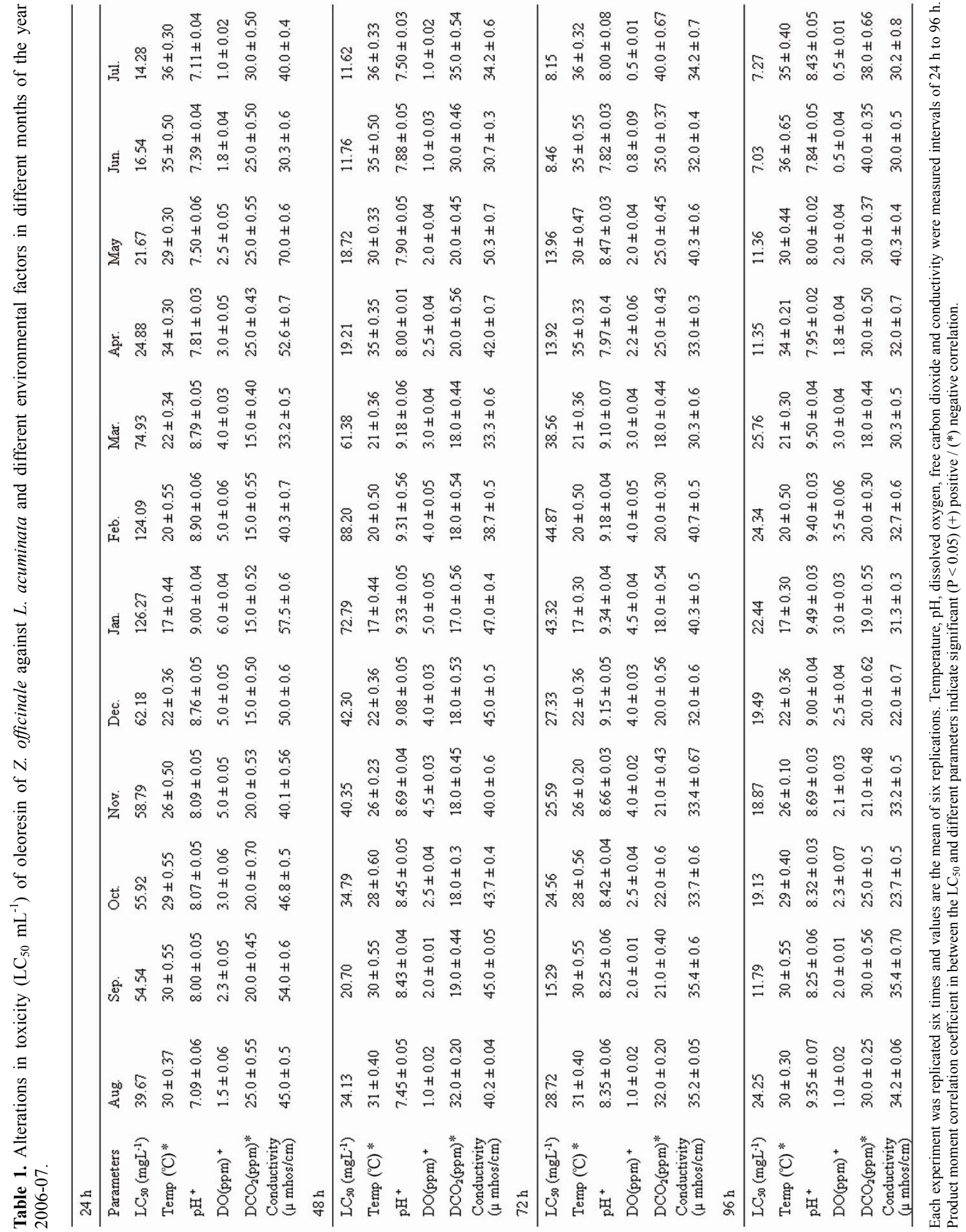


Table 2. Effect of $24 \mathrm{~h}$ exposure of $40 \%$ and $80 \%$ of $24 \mathrm{~h} \mathrm{LC}$ 50 of oleoresin of Z. officinale in different months of the year $2006-07$ on acetylcholinesterase activity in the nervous tissue of $L$. acuminata.

\begin{tabular}{|c|c|c|c|c|}
\hline \multirow{2}{*}{ Months } & \multirow{2}{*}{$24 \mathrm{~h} \mathrm{LC}_{50} \mathrm{mgL}^{-1}$} & \multicolumn{3}{|c|}{ AChE- $\mu$ mole "SH" hydrolyzed / min / mg protein } \\
\hline & & Control $^{\text {a }}$ & $40 \%$ of $24 \mathrm{~h} \mathrm{LC}_{50}$ & $80 \%$ of $24 \mathrm{~h} \mathrm{LC} 50$ \\
\hline August & 39.67 & $\begin{array}{l}0.093 \pm 0.01 \\
\quad(100)\end{array}$ & $\begin{array}{c}0.091 \pm 0.01 \\
(97.84)\end{array}$ & $\begin{array}{c}0.088 \pm 0.01 \\
(94.62)\end{array}$ \\
\hline September & 54.54 & $\begin{array}{l}0.139 \pm 0.01 \\
\quad(100)\end{array}$ & $\begin{array}{l}0.136 \pm 0.01 \\
\quad(97.84)\end{array}$ & $\begin{array}{l}0.132 \pm 0.01 \\
\quad(94.96)\end{array}$ \\
\hline October & 55.92 & $\begin{array}{l}0.101 \pm 0.02 \\
\quad(100)\end{array}$ & $\begin{array}{l}0.099 \pm 0.01 \\
(98.02)\end{array}$ & $\begin{array}{c}0.097 \pm 0.02 \\
(96.04)\end{array}$ \\
\hline November & 58.79 & $\begin{array}{l}0.106 \pm 0.01 \\
\quad(100)\end{array}$ & $\begin{array}{l}0.103 \pm 0.02 \\
\quad(97.17)\end{array}$ & $\begin{array}{l}0.101 \pm 0.01 \\
\quad(95.28)\end{array}$ \\
\hline December & 62.18 & $\begin{array}{c}0.109 \pm 0.00 \\
\quad(100)\end{array}$ & $\begin{array}{l}0.107 \pm 0.01 \\
\quad(98.17)\end{array}$ & $\begin{array}{l}0.105 \pm 0.01 \\
\quad(96.33)\end{array}$ \\
\hline January & 126.27 & $\begin{array}{l}0.190 \pm 0.00 \\
\quad(100)\end{array}$ & $\begin{array}{l}0.189 \pm 0.01 \\
\quad(99.47)\end{array}$ & $\begin{array}{l}0.186 \pm 0.01 \\
\quad(97.89)\end{array}$ \\
\hline February & 124.09 & $\begin{array}{l}0.176 \pm 0.01 \\
\quad(100)\end{array}$ & $\begin{array}{l}0.175 \pm 0.00 \\
\quad(99.43)\end{array}$ & $\begin{array}{l}0.171 \pm 0.00 \\
\quad(97.16)\end{array}$ \\
\hline March & 74.93 & $\begin{array}{l}0.147 \pm 0.02 \\
\quad(100)\end{array}$ & $\begin{array}{l}0.142 \pm 0.01 \\
\quad(96.60)\end{array}$ & $\begin{array}{c}0.134 \pm 0.01 \\
\quad(91.16)\end{array}$ \\
\hline April & 24.88 & $\begin{array}{l}0.141 \pm 0.02 \\
\quad(100)\end{array}$ & $\begin{array}{l}0.137 \pm 0.01 \\
\quad(93.66)\end{array}$ & $\begin{array}{l}0.133 \pm 0.01 \\
\quad(84.51)\end{array}$ \\
\hline May & 21.67 & $\begin{array}{l}0.104 \pm 0.01 \\
\quad(100)\end{array}$ & $\begin{array}{l}0.101 \pm 0.02 \\
\quad(75.92)\end{array}$ & $\begin{array}{l}0.099 \pm 0.03 \\
\quad(70.37)\end{array}$ \\
\hline June & 16.54 & $\begin{array}{l}0.087 \pm 0.03 \\
\quad(100)\end{array}$ & $\begin{array}{l}0.083 \pm 0.02 \\
(62.19)\end{array}$ & $\begin{array}{l}0.074 \pm 0.02 \\
\quad(59.75)\end{array}$ \\
\hline July & 14.28 & $\begin{array}{l}0.082 \pm 0.02 \\
\quad(100)\end{array}$ & $\begin{array}{c}0.073 \pm 0.01 \\
(63.41)\end{array}$ & $\begin{array}{l}0.071 \pm 0.01 \\
\quad(56.09)\end{array}$ \\
\hline
\end{tabular}

Values are mean \pm SE of six replicates. Value in parenthesis indicates \% enzyme activity with untreated control taken as $100 \%$. Rank correlation coefficient in between $\mathrm{LC}_{50}$ and $\mathrm{AChE}$ activity in treated group indicate significant $(\mathrm{P}<0.05)$ positive $(+)$ correlation. a, Significant $(\mathrm{P}<0.05)$ when one way of $\mathrm{ANOVA}$ was applied in between the enzyme activity in different months of the year in control group without treatment.

Table 3. Effect of $24 \mathrm{~h}$ exposure of $40 \%$ and $80 \%$ of $24 \mathrm{~h} \mathrm{LC} \mathrm{L}_{50}$ of oleoresin of $Z$. officinale in different months of the year $2006-07$ on alkaline phosphatase activity in the nervous tissue of L. acuminata.

\begin{tabular}{|c|c|c|c|c|}
\hline \multirow{2}{*}{ Months } & \multirow{2}{*}{$24 \mathrm{~h} \mathrm{LC}_{50} \mathrm{mgL}^{-1}$} & \multicolumn{3}{|c|}{ ALP- $\mu$ moles / $30 \mathrm{~min} / \mathrm{mg}$ protein } \\
\hline & & Control & $40 \%$ of $24 \mathrm{~h} \mathrm{LC}_{50}$ & $80 \%$ of $24 \mathrm{~h} \mathrm{LC} 50$ \\
\hline August & 39.67 & $\begin{array}{l}2.27 \pm 0.01 \\
(100)\end{array}$ & $\begin{array}{c}2.17 \pm 0.01 \\
(95.59)\end{array}$ & $\begin{array}{c}2.14 \pm 0.01 \\
(94.27)\end{array}$ \\
\hline September & 54.54 & $\begin{array}{c}3.34 \pm 0.01 \\
(100)\end{array}$ & $\begin{array}{c}3.31 \pm 0.01 \\
(99.10)\end{array}$ & $\begin{array}{c}3.27 \pm 0.01 \\
(97.90)\end{array}$ \\
\hline October & 55.92 & $\begin{array}{c}3.27 \pm 0.01 \\
\quad(100)\end{array}$ & $\begin{array}{c}3.23 \pm 0.02 \\
(98.77)\end{array}$ & $\begin{array}{c}3.19 \pm 0.02 \\
(97.55)\end{array}$ \\
\hline November & 58.79 & $\begin{array}{c}3.36 \pm 0.02 \\
(100)\end{array}$ & $\begin{array}{c}3.32 \pm 0.02 \\
(98.80)\end{array}$ & $\begin{array}{c}3.27 \pm 0.00 \\
(97.32)\end{array}$ \\
\hline December & 62.18 & $\begin{array}{c}3.11 \pm 0.00 \\
\quad(100)\end{array}$ & $\begin{array}{c}3.06 \pm 0.02 \\
(98.39)\end{array}$ & $\begin{array}{c}3.02 \pm 0.02 \\
(97.10)\end{array}$ \\
\hline January & 126.27 & $\begin{array}{l}2.89 \pm 0.01 \\
\quad(100)\end{array}$ & $\begin{array}{l}2.85 \pm 0.00 \\
\quad(98.62)\end{array}$ & $\begin{array}{l}2.81 \pm 0.01 \\
\quad(97.23)\end{array}$ \\
\hline February & 124.09 & $\begin{array}{l}3.07 \pm 0.01 \\
\quad(100)\end{array}$ & $\begin{array}{l}3.02 \pm 0.01 \\
(98.37)\end{array}$ & $\begin{array}{l}2.98 \pm 0.01 \\
(97.06)\end{array}$ \\
\hline March & 74.93 & $\begin{array}{c}3.10 \pm 0.00 \\
(100)\end{array}$ & $\begin{array}{c}3.07 \pm 0.00 \\
(99.03)\end{array}$ & $\begin{array}{c}3.02 \pm 0.01 \\
(97.41)\end{array}$ \\
\hline April & 24.88 & $\begin{array}{l}3.45 \pm 0.01 \\
\quad(100)\end{array}$ & $\begin{array}{l}3.42 \pm 0.02 \\
(99.13)\end{array}$ & $\begin{array}{c}3.37 \pm 0.02 \\
(97.68)\end{array}$ \\
\hline May & 21.67 & $\begin{array}{l}2.94 \pm 0.02 \\
\quad(100)\end{array}$ & $\begin{array}{l}2.89 \pm 0.00 \\
(98.29)\end{array}$ & $\begin{array}{l}2.86 \pm 0.03 \\
(97.28)\end{array}$ \\
\hline June & 16.54 & $\begin{array}{c}1.86 \pm 0.03 \\
\quad(100)\end{array}$ & $\begin{array}{l}1.74 \pm 0.02 \\
(93.55)\end{array}$ & $\begin{array}{c}1.64 \pm 0.02 \\
(88.17)\end{array}$ \\
\hline July & 14.28 & $\begin{array}{l}2.36 \pm 0.01 \\
\quad(100)\end{array}$ & $\begin{array}{l}2.23 \pm 0.01 \\
(94.49)\end{array}$ & $\begin{array}{l}2.16 \pm 0.02 \\
\quad(91.52)\end{array}$ \\
\hline
\end{tabular}

Values are mean \pm SE of six replicates. Value in parenthesis indicates \% enzyme activity with untreated control taken as $100 \%$. Rank correlation coefficient in between $\mathrm{LC}_{50}$ and ALP activity in treated group indicate non significant $(\mathrm{P}<0.05)$ positive correlation. a, Significant $(\mathrm{P}<0.05)$ when one way of $\mathrm{ANOVA}$ was applied in between the enzyme activity in different months of the year in control group without treatment. 
(ACP) $\left(\tau=0.606 ; P=0.05-40 \%\right.$ of $24 \mathrm{~h} \mathrm{LC}_{50}, \tau=0.606$; $P=0.05-80 \%$ of $24 \mathrm{~h} \mathrm{LC}_{50}$ ) activity in the nervous tissue of $L$. acuminata exposed to sub-lethal treatments of oleoresin in different months. Maximum inhibition in ACP activity (91.00\% of control) was observed in snails exposed to $80 \%$ of $24 \mathrm{~h} \mathrm{LC}_{50}$ in July (Table 4).

\section{DISCUSSION}

It is clear from result section that toxicity of oleoresin varies with changes in abiotic environmental factors in the water. Effect of abiotic variants in aquatic environment i.e. $\mathrm{pH}$ [20], Temperature [21] on the toxicity of different pesticides have been reported. The temperature of water is a significant factor, which alters the toxicity of oleoresin in each month of the year. When the water temperature is higher in summer season June-July, the toxicity of oleoresin is maximum. Contrarily, in winter season, the temperature of water is low and toxicity of oleoresin is less as evident by higher $\mathrm{LC}_{50}$ value. Temperature of environment in which the animal resides is a crucial factor, when toxicity of pesticides is determined [22-25]. Osterauer and Kohler [26] reported that the toxicity of diazinon against zebra fish strongly increased at elevated temperature. Dissolved oxygen is also one of the factors, which alter the toxicity of oleoresin. Water in winter season holds more oxygen [27] and as a result, less mortality of snails occurs during this period. At higher water temperature dissolved oxygen concentration decreases which is reflected by higher mortality of the snails. Dissolved oxygen is one of the major components, which is required by snails during metabolic activity $[28,29]$. Consequently, at higher temperature, increasing rate of metabolism in snail body may release more $\mathrm{CO}_{2}$, which affects the $\mathrm{pH}$ of water [30,31] As the time duration increases concentration of $\mathrm{CO}_{2}$ increases in the water (released by snails) and it also affects the $\mathrm{pH}$ of water. Murphy [32] reported that pesticides belonging to organophosphate and carbamate groups are very sensitive to change in $\mathrm{pH}$. Earlier Vasconcellos [33] observed the influence of $\mathrm{pH}$ variation on the molluscicidal activity of Euphorbia splendens latex. According to them molluscicidal activity was maximum at $\mathrm{pH} 5.0-6.0$ and minimum at $\mathrm{pH} 7.0-8.0$. Toxicity of oleoresin is highest at high temperature, $\mathrm{CO}_{2}$ of water as well as low $\mathrm{pH}$, dissolved $\mathrm{O}_{2}$ of water. The low concentration of dissolved $\mathrm{O}_{2}$ act as physical stressor on aquatic animals [34] and in the absence of sufficient dissolved $\mathrm{O}_{2}$; the snails appear to become more sensitive against the molluscicide. The pungent moieties of oleoresin are gingerol, zingirone and shogaol [35]. It is conceivable that, the active molluscicidal component, present in the oleoresin might get converted into a more toxic form in the aquarium water

Table 4. Effect of $24 \mathrm{~h}$ exposure of $40 \%$ and $80 \%$ of $24 \mathrm{~h} \mathrm{LC}_{50}$ of oleoresin of Z. officinale in different months of the year $2006-07$ on acid phosphatase activity in the nervous tissue of $L$. acuminata.

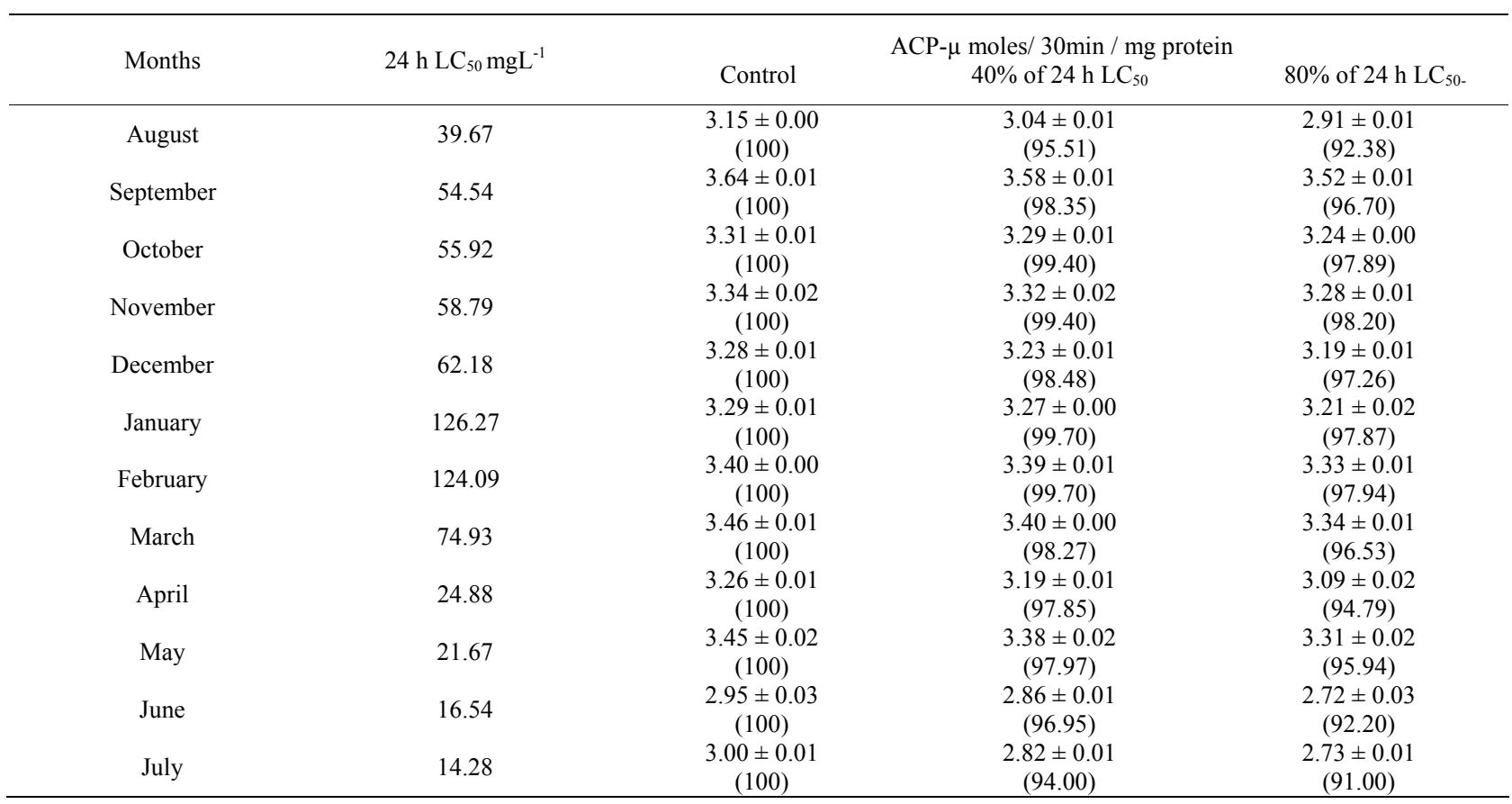

Values are mean \pm SE of six replicates. Value in parenthesis indicates $\%$ enzyme activity with untreated control taken as $100 \%$. Rank correlation coefficient in between $\mathrm{LC}_{50}$ and ACP activity in treated group indicate significant $(\mathrm{P}<0.05)$ positive $(+)$ correlation. a, Significant $(\mathrm{P}<0.05)$ when one way of ANOVA was applied in between the enzyme activity in different months of the year in control group without treatment. 
or in the snail body due to variant environmental factors in the month of June and July. Earlier, it has been shown that the treatment of oleoresin of $Z$. officinale caused significant inhibition of AChE, ALP and ACP activity in the nervous tissue of $L$. acuminata [9]. The high anti $\mathrm{AChE}$ and ACP activity of oleoresin of $Z$. officinale was observed in months of June-July. The enzyme ALP plays a critical role in protein synthesis [36] and secretary activity [37] is comparatively less inhibited than AChE. Acid phosphatase (ACP), a lysosomal enzyme [38], plays an important role in autolysis and phagocytosis, pathological necrosis, and overall catabolism $[8,10,39]$ was reduced significantly. Earlier, it has been observed that increased activity of ACP causes breakdown of existing protein in L. acuminata [18], but inhibition of ACP activity in this study indicates that it is not used in breakdown of cellular protein. The rank correlation coefficient applied between the $\mathrm{LC}_{50}$ values of different months and the corresponding inhibition in enzyme activity, point out a positive correlation between the $\mathrm{LC}_{50}$ and the inhibition of AChE and ACP. Whereas there was no correlation in between $\mathrm{LC}_{50}$ and ALP activity indicate that ALP is not altered by action of oleoresin in different months.

Accurate prediction of molluscicide fate and toxicity in aqueous environment against snails are hindered due to lack of information that how abiotic factors of aqueous environment affect the biological activity and related toxicity of molluscicides. Abiotic factors are not only correlated with the lethality of molluscicide, but with each other also. The present study conclusively shows that variant abiotic factors can significantly alter the toxicity of oleoresin of $Z$. officinale in L. acuminata. It is also obvious that the most suitable period for the control of this snail in India is the month of June, July. It is suggested that the treatment of a water body with oleoresin of $Z$. officinale for the control of $L$. acuminata and ultimately fascioliasis, is not only more potent and cost effective during these months than spending more money by using higher concentrations of this molluscicide during the rest ten months of the year.

\section{REFERENCES}

[1] Singh, S., Singh, V.K. and Singh, D.K. (1997) Molluscicidal activity of some common spice plants. Biological Agriculture and Horticulture, 14, 237-249.

[2] Shukla, S., Singh, V.K. and Singh, D.K. (2006) The effect of single, binary, tertiary, combination of few plant derived molluscicides alone or in combination with synergist on different enzymes in the nervous tissues of the freshwater snail Lymnaea (Radix) acuminata (Lamark). Pesticide Biochemistry and Physiology, 85, 167-173.

[3] Singh, O. and Agarwal, R.A. (1981) Toxicity of certain pesticides to two economic species of snails in northern
India. Journal of Economic Entomology, 74, 568-571.

[4] World Health Organization. (2006) Report of the WHO informal meeting on use of triclabendazole in fascioliasis control. WHO headquarters, Geneva, Switzerland, 17-18 October 2006.

[5] Singh, P., Singh, V.K. and Singh, D.K. (2005) Effect of binary combination of some plant-derived molluscicides with MGK-264 or piperonyl butoxide on the reproduction of the snail Lymnaea acuminata. Pest Management Science, 61, 204-208.

[6] Kumar, P. and Singh, D.K. (2006) Molluscicidal activity of Ferula asafoetida, Syzygium aromaticum and Carum carvi and their active components against the snail Lymnaea acuminata. Chemo, 63, 1568-1574.

[7] Kumar, P., Singh, V.K. and Singh, D.K. (2009) Kinetics of enzyme inhibition by active molluscicidal agents ferulic acid, umbelliferone, eugenol and limonene in the nervous tissue of snail Lymnaea acuminata. Phytotherapy Research, 23, 172-177.

[8] Jaiswal, P., Singh, V.K. and Singh, D.K. (2008) Enzyme inhibition by molluscicidal component of Areca catechu and Carica papaya in the nervous tissue of vector snail Lymnaea acuminata. Pesticide Biochemistry and Physiology, 92, 164-168.

[9] Singh, K. and Singh, D.K. (2000) Toxicity to the snail Lymnaea acuminata of plant-derived molluscicides in combination with synergists. Pest Management Science, 56, 889-898.

[10] Tripathi, S.M., Singh, V.K., Singh, S. and Singh, D.K. (2004) Enzyme inhibition by the molluscicidal agent $P u$ nica granatum Linn. bark and Canna indica Linn. root. Phytotherapy Research, 18, 501-506.

[11] Gunther, E. (1975) The essential oils. Robert, E Krieger Publishing Company, NewYork.

[12] American Public Health Association (APHA). (2005) Standard methods for the examination of water and wastewater. 21st Edition, Washington, D.C.

[13] Robertson, J.L., Russell, R.M., Preisler, H.K. and Savin, N.E. (2007) Bioassay with Arthropods POLO computer programme for analysis of bioassay data. 2nd Edition, CRC Press, Talor and Francis, 1-224.

[14] Sokal, R.R. and Rohlf, F.J. (1973) Introduction to biostatistics. W. H. Freeman \& Co., Ltd., San Francisco.

[15] Ellman, G.L., Courtney, K.D., Andres, V. and Featherstone, R.M. (1961) A new and rapid colorimetric determination of acetylcholinesterase activity. Bio Pharmacol, 7, 88-95.

[16] Singh, D.K., Singh, O. and Agarwal, R.A. (1982) Comparative study of cholinesterase in two snails. Pila globosa and Lymnaea acuminata. The Journal of Physiology, 78, 467-472.

[17] Bergmeyer, U.H. (1967) Methods of enzymatic analysis. Academic Press, New York, 1129.

[18] Singh, D.K. and Agarwal, R.A. (1989) Toxicity of piperonyl butoxide carbaryl synergism on the snail Lymnaea acuminata. Internationale Revue der gesamten $\mathrm{Hy}$ drobiologie und Hydrographie, 74, 689-699.

[19] Lowry, O.H., Rosebrough, N.J., Farr, A.L. and Randall R.J. (1951) Protein measurement with folin phenol reagent. The Journal of Biological Chemistry, 193, 265-275.

[20] Watson, S.J. and Maly, E.J. (1987) Thiocyanate toxicity to Daphina magna: Modified by $\mathrm{pH}$ and temperature. Aqua- 
tic Toxicol, 10, 1-8.

[21] Sogorb, A., Andreu-Moliner, E.S., Almar, M.M., del Ramo, J. and Nunez, A. (1988) Temperature-toxicity relationship of fluvalinate (synthetic pyrethroid) on Procambarus clarkia (Girard) under laboratory conditions. Bull Environ Cantam Toxicol, 40, 13-17.

[22] Schott, J.G. and Georghion, G.P. (1984) Influence of temperature on knockdown, toxicity and resistance to pyrethroids in the house fly, Musca domestica. Pesticide Biochemistry and Physiology, 21, 53-62.

[23] Ferrando, M.D., Andreu-Moliner, E.S., Almar, M.M., Cerebrian, C. and Nunez, A. (1987) Acute toxicity of organochlorine pesticides to the European eel, Anguilla anguilla. The dependency on exposure time and temperature. Bulletin of Environmental Contamination and Toxicology, 39, 365-369.

[24] Schott, J.G. (1995) Effects of temperature on insecticides toxicity. In: Roe, R.M. and Kuhr, R.J. Eds., Reviews in Pesticide Toxicology, North Carolina State University, Raleigh, 111-135.

[25] Young, C. (1996) Metal chelates as stomach poison molluscicides for introduced pests, Helix aspersa, Theba pisana, Cernuella virgata and Deroceras reticulatum in Australia. In: Henderson, I.F. Ed., Slug and Snail Pests in Agriculture, British Crop Protection Council, Farnham, 237-243.

[26] Osterauer, R. and Kohler, H.R. (2008) Temperature-dependent effects of the pesticides thiacloprid and diazinon on the embryonic development of zebra fish (Danio rerio). Aquatic Toxicol, 86, 485-494.

[27] Waterwatch Australia. (2002) National Technical Manual. Module 4: Physical and chemical parameters. Waterwatch Australia Steering Committee Environment Australia. http://www.waterwatch.org.au

[28] Ishak, M.M. and Mohamed, A.M. (1975) Effect of sublethal doses of copper sulphate and bayluscide on survival and oxygen consumption of the snail Biomphalaria alexandrina. Hydrobiol, 47, 499-512.

[29] Watten, B.J. (2004) Method and apparatus for control of aquatic vertebrate and invertebrate invasive species. US Patent No. 6821442, 23 November 2004.

[30] Toews, K.L., Shroll, R.M., Wai, C.M. and Smart, N.G. (1995) $\mathrm{pH}$ - Defining equilibrium between water and su- percritical $\mathrm{CO}_{2}$ - influence on SFE of organics and metal chelates. Analytical Chemistry, 67, 4040-4043.

[31] Berge, J.A., Bjerkeng, B., Pettersen, O., Schaanning, M.T. and Oxnevad, S. (2006) Effects of increased sea water concentrations of $\mathrm{CO}_{2}$ on growth of the bivalve Mytilus edulis L. Chemo, 62, 681-687.

[32] Murphy, G. (2004) Water pH and its Effect on Pesticides. Ministry of Agriculture and Food Ontario, Canada http://www.gov.on.ca/OMAFRA/english/crops/hort/news /grower/2004/08gn04a1.htm

[33] Vasconcellos, M.C. and Amorim, A. (2003) Molluscicidal action of the latex of Euphorbia splendens var. hislopii NEB (Christ Crown) (Euphorbiaceae) against Lymnaea columella (Say, 1817) (Pulmonata; Lymnaeidae), Intermediate host of Fasciola hepatica (Linn. 1758) (Trematode: Fasciolidae). 1-Test in laboratory. Mem Inst Oswaldo Cruz, Rio de Janeiro, 98, 557-563.

[34] Irving, E.C., Lowell, R.B., Culp, J.M., Liber, K., Xie, Q. and Kerrich, R. (2008) Effects of arsenic speciation and low dissolved oxygen condition on the toxicity of the arsenic to a lotic Mayfly. Environmental Toxicology \& Chemistry, 27, 593-590.

[35] Mustafa, T., Srivastava, K.C. and Jensen, K.B. (1993) Drug development report (9) Pharmacology of ginger Zingiber officinale. Journal of Drug Development, 6, 2539.

[36] Pilo, B., Asnani, M.B. and Shah, R.V. (1972) Studies on wound healing and repair in pigeon liver III. Histochemical studies on acid and alkaline phosphatase activity during the process. J Ani Mor Phy, 19, 205-212.

[37] Ibrahim, A.M., Migazi, M.G. and Dexian, E.S. (1974) Histochemical localization of alkaline phosphatase activity in the alimentary tract of the snail Marisa coruarielis (1). Bul Zoo Soc Egy, 26, 95-105.

[38] Aruna, P., Chetty, C.S., Naidu, R.C. and Swami, K.S (1979) Acid phosphatase activity in the Indian apple snail Pila globosa (Swainsen) during aestivation and starvation stress. Proceedings of Indian Academy Science (India), 88, 363-365.

[39] Abou-Donia, M.B. (1978) Increased acid phosphatase activity in hens following oral dose of Leptophos. Toxicology Letters, 2, 199-203. 